\title{
Ethnopharmacological survey of home remedies used for treatment of hair and scalp and their methods of preparation in the West Bank-Palestine
}

Abdel Naser Zaid ${ }^{1 *}$, Nidal Amin Jaradat ${ }^{1}$, Ahmad Mustafa Eid ${ }^{1}$, Hamzeh Al Zabadi $^{2}$, Abdulsalam Alkaiyat ${ }^{2}$ and Saja Adam Darwish ${ }^{1}$

\begin{abstract}
Background: Natural products have many uses and purposes, including those linked to pharmaceutics and cosmetics. The aim of this study was to investigate the use of natural remedies for the treatment of hair and scalp disorders in the West Bank, Palestine.

Methods: An ethnopharmacological survey of herbal remedies and other natural products used in cosmetics and cosmeceuticals was carried out in the West Bank, Palestine. A questionnaire was distributed to 267 herbalists, traditional healers, hairdressers and rural dwellers. Collected information included: the names of plants and other natural products, the parts used, hair conditions, diseases and problems for which these products were used and also their methods of preparation. To identify the most important species used, the factor of informant's consensus ( $\left.F_{i d}\right)$, fidelity level (FI) and the use-value (UV) were calculated.

Results: Collected data showed that 41 plants are utilized for the treatment of hair and scalp disorders, belonging to 27 families; among them Lamiaceae and Rosaceae, which were the most commonly used. Plant oils and their fruits are the most commonly used parts. Hair loss, dandruff, split hair endings and lice treatment, are reported as the most treated disorders. The number of plant species used consisted of 19,14,13, and again 13 with a factor of informant's consensus (Fic) for these disorders corresponding to $0.93,0.94,0.95$ and 0.92 , respectively. Fl was 100\% for many plants; the highest UV value (0.84) was registered for Lawsonia inermis, which belongs to the Lythraceae family.

Conclusions: This study showed that many natural remedies are still used in Palestine for the treatment of scalp and hair disorders as well as for cosmeceutical purposes. This study is of great importance as it allows us to have a greater perspective on our folkloric use of these natural products. A combined scientific effort between informants and the scientific community, working in this field, may help in the discovery of new cosmetics, cosmeceutical and nutraceutical products.
\end{abstract}

Keywords: Ethnopharmacology, Cosmetics, Cosmeceutical, Herbals, Minerals, Animals

\footnotetext{
* Correspondence: anzaid@najah.edu

${ }^{1}$ Department of Pharmacy, Faculty of Medicine and Health Sciences,

An-Najah National University, P.O. Box 7, Nablus, Palestine

Full list of author information is available at the end of the article
} 


\section{Background}

Palestine, also known as the Holy Land, has great ethnic variability: Muslims, Christians, Druze, Jews from East and West and Samaritans. Such a variety has enriched its culture, especially that of a folkloric nature, herbal foods, medicines and cosmetics. Thus the holy land is a unique area in its ecological diversity due to its geographical location in the Mediterranean region. Varied zoogeographic, climatic, and phytogeographic zones cover Palestine hence generating great biological multidiversity [1]. In addition to this, it has been an important international trade cross road since the ancient times, between the Eastern and Western worlds, further enriching its culture in herbal remedies and home uses [2-4].

Cosmetics such as perfumes and soaps have been used and developed by people for decades [5-8]. Based on the European Commission [9], cosmetic products have been defined, "as any substance or preparation intended to be placed in contact with the external parts of the human body or with the teeth and the mucous membranes of the oral cavity with a view exclusively or mainly to cleaning them, perfuming them, changing their appearance, and/or correcting body odors and/or protecting or keeping them in good condition". Accordingly, cosmetics can be classified according to the following classes: (i) skin care cosmetics, (ii) makeup cosmetics, (iii) perfume and eau de cologne, (iv) hair care products, and (v) special-purpose cosmetics. The merging of pharmaceutics and cosmetics is known as cosmeceuticals, which consists of products with medicinal properties that shows beneficial topical actions and provides protection against degenerative skin conditions $[10,11]$.

Herbs, animals, and minerals provide a continuous source of food, medicines and cosmetics for humans, which have been long used in several forms including: (i) decoctions, (ii) syrups, (iii) liniments, (iv) powders, (v) infusions, (vi) gels and magmas, (vii) creams, pastes and ointments [12,13]. In 1960, proof of medicinal herbal and plant use, in the Mediterranean area, was discovered, to be existing, in a cave from, approximately, 60,000 years ago [14]. More recently, people in both developed and developing countries utilize medicines and cosmetic preparations obtained from natural sources for the improvement of their health and aesthetic appearance $[15,16]$. According to the World Health Organization (WHO), about $80 \%$ of populations in developing countries have utilized ethnomedicines for their health care. The plants, commonly used in domestic medicine and home remedies, by those of different cultures, are traditionally used for the remedy of hair and scalp diseases where the main focus, currently, is on their "cosmeceutical" purposes. However we need to appreciate that medical anthropological aspects of the etiology of some hair and scalp afflictions are very complex and are not always completely understood $[17,18]$.

\section{Methods}

An ethnopharmacological survey on herbal, mineral and animal products, used as cosmetics or cosmeceuticals, in the treatment of hair and scalp disorders, was conducted from April to June 2016. The visited and interviewed areas consisted of all of the regions of the West Bank, Palestine: Nablus, Jenin, Tubas, Tulkarm, Salfeit, Qalqilya, Ramallah, Jericho, Jerusalem, Bethlehem and Hebron (Fig. 1).

The Institutional Review Board (IRB) at An-Najah National University approved the aims of this study, its protocols, and the informed consent forms; IRB archived number 9/April/2016. This study was carried out according to the requirements of the declarations of Helsinki.

The study was carried out using the method of interviews with herbalists, traditional healers, hairdressers and rural dwellers that used herbal remedies in the treatment of different types of hair and scalp disorders and for the alteration of their aesthetic appearance. These informants represented most of the practitioners in this field in the West Bank (Socio-demographic characteristics are presented in Table 1).

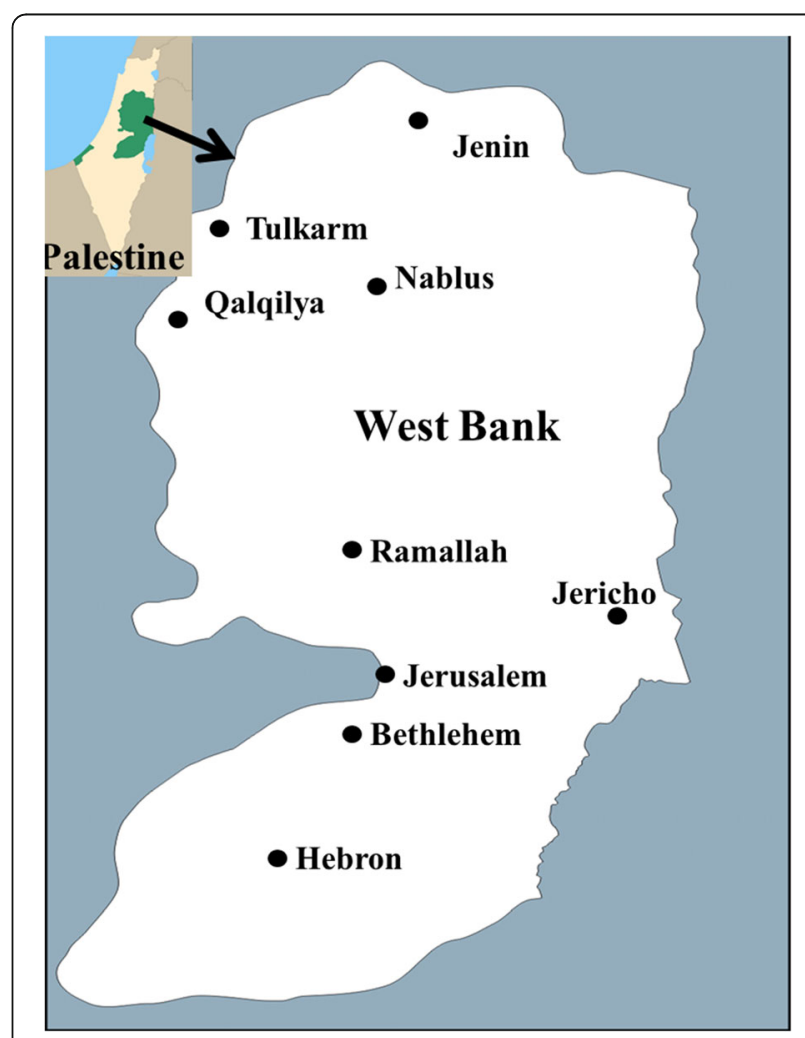

Fig. 1 Map of the West Bank/ Palestine showing all surveyed regions 
Table 1 Socio-demographic characteristics of the study population $(N=267)$

\begin{tabular}{|c|c|}
\hline Variable & $\mathrm{n}(\%)^{\mathrm{a}}$ \\
\hline \multicolumn{2}{|l|}{ Age (year) } \\
\hline $16-29$ & $129(48.3)$ \\
\hline 30-39 & $67(25.1)$ \\
\hline $40-49$ & $50(18.7)$ \\
\hline $50-59$ & $17(6.4)$ \\
\hline$\geq 60$ & $4(1.5)$ \\
\hline \multicolumn{2}{|l|}{ Education } \\
\hline Illiterate level & $6(2.2)$ \\
\hline Elementary or preparatory level & $23(8.6)$ \\
\hline Secondary level & $70(26.2)$ \\
\hline University level & $168(62.9)$ \\
\hline \multicolumn{2}{|l|}{ Income } \\
\hline Low & $14(5.2)$ \\
\hline Medium & $229(85.8)$ \\
\hline High & $24(9.0)$ \\
\hline \multicolumn{2}{|l|}{ Material status } \\
\hline Single & $115(43.1)$ \\
\hline Married & $144(53.9)$ \\
\hline Others (divorced or widow) & $8(3.0)$ \\
\hline \multicolumn{2}{|l|}{ Place of residence } \\
\hline City & $116(43.4)$ \\
\hline Village & $145(54.3)$ \\
\hline Refugee camp & $6(2.2)$ \\
\hline \multicolumn{2}{|l|}{ Knowledge of natural products } \\
\hline Media (TV, Radio, Journals...etc) & $46(17.2)$ \\
\hline Relatives and friends & $108(40.4)$ \\
\hline Attarine (herbalists) & $11(4.1)$ \\
\hline Physicians & $2(0.7)$ \\
\hline Pharmacists & $11(4.1)$ \\
\hline Internet & $88(33.0)$ \\
\hline Other sources & $1(0.4)$ \\
\hline \multicolumn{2}{|l|}{ Obtainment of the natural products } \\
\hline Attarine (herbalists) & $194(72.7)$ \\
\hline Pharmacies & $32(12.0)$ \\
\hline Friends & $3(1.1)$ \\
\hline Wild and nature & $38(14.2)$ \\
\hline
\end{tabular}

${ }^{a}$ Data are presented as frequency (percent) from the total population studies $(N=267)$

A sufficient sample of herbalists and cosmetic practitioners, from various regions, were met by researchers and asked to answer a face-to-face questionnaire. They were interviewed in Arabic after getting their verbal consent only once.
Questionnaires were administered through personal contact discussions. This method is an effective and easy option for data collection. The objective of this survey was to obtain information on several issues including: (i) the names of plant, mineral and animal products commonly used as cosmeceuticals for the hair and scalp, (ii) the type of aesthetic purpose or disorder treated by these natural products, (iii) the methods of preparing and (iv) parts used for cosmeceutical treatment. For the aim of obtaining clear information, names of plants or other natural products were translated later into English and Latin. In most cases, the interviews often started in the form of informal discussions to obtain the confidence of the interviewees.

All of the 41 plants and 10 other natural products, minerals and animals products, were collected from the interviewees (herbalists, traditional healers, hairdressers and rural dwellers) and kept in special glass frames and later identified by the pharmacognosist Dr. Nidal Jaradat. The identity of each plant species mentioned by the interviewees was confirmed and verified by using photographs and live specimens. A medicinal use was accepted as valid only if it was mentioned by at least three independent herbal practitioners. Samples of these collected herbs were given a herbarium specimen number as shown in Table 2 and voucher samples were kept at the Pharmacognosy Laboratory of the Department of Pharmacy, Faculty of Medicine and Health Sciences at An-Najah National University.

\section{Data analysis}

Statistical analyses were performed by using the Statistical Package for Social Sciences (SPSSversion17.0).

All citations were placed into ailment categories for each type of cancer. The factor of informant's consensus $\left(F_{\text {ic }}\right)$ was employed to indicate how homogenous the information was. In fact, its main use is to select the disease categories where there is consensus on the use of plants among the informants. The $F_{i c}$ value is close to 0 if plants are chosen randomly or if informants do not exchange information about their use. High values of $F_{\text {ic }}$ (close to 1 ) occur when there is a well-defined selection criterion in the community and/or if information is frequently exchanged between informants [19].

The $F_{\text {ic }}$ is calculated as in the following equation:

$$
F_{i c}=\frac{N u r-N t}{N u r-1}
$$

Where Nur is the number of use citations in each category and $\mathrm{Nt}$ is the number of taxa used. 
Table 2 Herbals used in the treatment of hair and scalp in the West Bank/Palestine

\begin{tabular}{|c|c|c|c|}
\hline Plant names (Latin, English and Arabic names) with their voucher specimen codes & Family & Citations & Use value \\
\hline Allium cepa L./ Onion/بصل/ IPharm-PCT-2703 & Amaryllidaceae & 34 & 0.13 \\
\hline Allium sativum L./ Garlic/ثوم/Pharm-PCT-2704 & Amaryllidaceae & 156 & 0.58 \\
\hline Nigella arvensis L./ Nigella/ قزحهد/ Pharm-PCT-1640 & Ranunculaceae & 28 & 0.10 \\
\hline Petroselinum crispum (Mill.) Fuss/Parsley/ قدونس// Pharm-PCT-2739 & Apiaceae & 8 & 0.03 \\
\hline Pimpinella anisum L./Anise/اليانسون /Pharm-PCT-2768 & Apiaceae & 38 & 0.14 \\
\hline Cocos nucifera L./ Coconut/جوز الهند/Pharm-PCT-2764 & Arecaceae & 84 & 0.31 \\
\hline Barbarea vulgaris R.Br./ Rocket cress/ جرجير/Pharm-PCT-2757 & Brassicaceae & 15 & 0.06 \\
\hline Raphanus raphanistrum subsp. sativus (L.) Domin / Fodder Radish/فجل/Pharm-PCT-2007 & Brassicaceae & 4 & 0.01 \\
\hline Anthemis cotula L./ Chamomile/البابونج/ Pharm-PCT-178 & Compositae & 46 & 0.17 \\
\hline Cucumis sativus L./ Cucumber/خيار/ Pharm-PCT-2737 & Cucurbitaceae & 18 & 0.07 \\
\hline Citrullus colocynthis (L.) Schrad. / Bitter Apple/ حنظل/ Pharm-PCT-628 & Cucurbitaceae & 8 & 0.03 \\
\hline Ricinus communis L./ Castor/خروع/Pharm-PCT-2742 & Euphorbiaceae & 173 & 0.65 \\
\hline Salvia fruticosa Mill./Sage/مريمية/Pharm-PCT-2117 & Lamiaceae & 16 & 0.06 \\
\hline Origanum syriacum L./Syrian oregano(Thyme)/ زعر/Pharm-PCT-1496 & Lamiaceae & 24 & 0.09 \\
\hline Rosmarinus officinalis L./Rosemary/اكليل الجبل/Pharm-PCT-2732 & Lamiaceae & 9 & 0.03 \\
\hline Mentha longifolia (L.) L./Mint/نعنع/Pharm-PCT-1566 & Lamiaceae & 4 & 0.01 \\
\hline Lavandula coronopifolia Poir./Lavender/خزامي/ Pharm-PCT-1367 & Lamiaceae & 4 & 0.01 \\
\hline Persea americana Mill./ Avocado/ الافوكادو/Pharm-PCT-2740 & Lauraceae & 23 & 0.09 \\
\hline Trigonella arabica Delile/ Fenugreek/حلبه/Pharm-PCT-2511 & Leguminosae & 64 & 0.24 \\
\hline Lawsonia inermis L./ Henna/حناء/ Pharm-PCT-2736 & Lythraceae & 223 & 0.84 \\
\hline Punica granatum L./ Pomegranate/رمان/ Pharm-PCT-2721 & Lythraceae & 28 & 0.10 \\
\hline Hibiscus sabdariffa L./ Roselle/كركدية/ Pharm-PCT-2752 & Malvaceae & 9 & 0.03 \\
\hline Abelmoschus esculentus (L.) Moench/ Okra/باميه/ Pharm-PCT-2772 & Malvaceae & 10 & 0.04 \\
\hline Azadirachta indica A.Juss./ Neem/نيم/Pharm-PCT-2769 & Meliaceae & 6 & 0.02 \\
\hline Musa paradisiaca L./ Banana/موز/ Pharm-PCT-2715 & Musaceae & 26 & 0.10 \\
\hline Myristica fragrans Houtt./ Nutmeg/جوزة الطيب/Pharm-PCT-2716 & Myristicaceae & 7 & 0.03 \\
\hline Melaleuca alternifolia (Maiden \& Betche) Cheel / Tea tree oil/شجرة الثاي/Pharm-PCT-2765 & Myrtaceae & 6 & 0.02 \\
\hline Syzygium aromaticum (L.) Merr. \& L.M.Perry/ Clove/كبش قرنفل/ Pharm-PCT-2767 & Myrtaceae & 22 & 0.08 \\
\hline Olea europaea L. / Olive/الزيتون/ Pharm-PCT-1664 & Oleaceae & 369 & 1.38 \\
\hline Sesamum indicum L./ Sesame/سمسم/Pharm-PCT-2722 & Pedaliaceae & 35 & 0.13 \\
\hline Prunus dulcis (Mill.) D.A.Webb/Almond/ لوز/Pharm-PCT-143 & Rosaceae & 76 & 0.28 \\
\hline Malus domestica Borkh./Apple vinegar/خل التفاح/Pharm-PCT-2766 & Rosaceae & 118 & 0.44 \\
\hline Rosa canina L./Rose/الورد الجوري/ Pharm-PCT-2052 & Rosaceae & 4 & 0.01 \\
\hline Citrus limon (L.) Osbeck /Lemon/ لمون/ Pharm-PCT-2741 & Rutaceae & 82 & 0.31 \\
\hline Aegle marmelos (L.) Corrêa /Quince/سفرجل/Pharm-PCT-2702 & Rutaceae & 11 & 0.04 \\
\hline Simmondsia chinensis (Link) C.K. Schneid. /Jojoba/جوجوبا/Pharm-PCT-2771 & Simmondsiaceae & 5 & 0.02 \\
\hline Capsicum frutescens L./ Chili pepper/ الفليفلة الثجيرية/ Pharm-PCT-2760 & Solanaceae & 6 & 0.02 \\
\hline Camellia sinensis (L.) Kuntze/ Green tea/شاي اخضر/Pharm-PCT-2706 & Theaceae & 32 & 0.12 \\
\hline Urtica pilulifera L./ Nettle/قريص/Pharm-PCT-2561 & Urticaceae & 11 & 0.04 \\
\hline Aloe vera (L.) Burm.f. /Aloe/ صبار/Pharm-PCT-115 & Xanthorrhoeaceae & 85 & 0.32 \\
\hline Zingiber officinale Roscoe/Ginger/زنجيل/Pharm-PCT-2724 & Zingiberaceae & 14 & 0.05 \\
\hline
\end{tabular}

Fidelity level (Fl) was defined as the ratio between the number of informants who independently suggested the use of a species for the same major purpose and the total number of informants who mentioned the plant for any use. $\mathrm{Fl}$ is of equal importance to $\mathrm{F}_{\mathrm{ic}}$ and it can be calculated according to the following equation: 


$$
F l=\frac{N p}{N} * 100
$$

Where $\mathrm{Np}$ is the number of informants that reported a use of a plant species to treat a particular disease and $\mathrm{N}$ is the number of informants that used the plants as a medicine to treat any given disease.

The use-value (UV) is a quantitative method that can be used in order to prove the relative importance of species known locally. It can be calculated according to the following equation:

$$
\mathrm{UV}=\frac{\sum U}{n}
$$

Where UV is the use value of a species; $U$ is the number of citations per species; $n$ is the number of informants.

Results of calculated $\mathrm{F}_{\mathrm{IC}}, \mathrm{Fl}$, and $\mathrm{UV}$ are shown in Tables 2, 3, 4 and 5.

\section{Results}

Table 1 summarizes the Socio-demographic characteristics of our sample of 267 women included in the study. Respondents belong to all age groups but mostly (48.3\%) were 1629 years of age. They are from various educational backgrounds with the majority of them (62.9\%) being from university-educated backgrounds, whilst the minority $(10.8 \%)$, were from an elementary level of education or illiterate. This ratio of illiterate versus university graduated women, who participated in this study, sounds consistent with the most recent status of education in Palestine. We also sampled across income $(85.8 \%$ were of medium income) and marital status (53.9\% married women, $43.1 \%$ single and 3\% were divorced or widowed). Knowledge of natural products was also investigated; most of them obtained their information from relatives and friends (40.4\%), the internet (33.0\%). Most of them (72.7\%) obtained the natural products they used from "Attarine;" merchants who sell herbs and natural products.

\section{Diversity of plants traditionally used in local cosmetics} In total, 41 plant species distributed across 40 genera and 27 families were reported as locally and traditionally used cosmetics and cosmeceuticals for the hair and scalp in Palestine, which were presented in Table 2 and the family use value is explained in Fig. 2. The largest families of cosmetic plants were Lamiaceae and Rosaceae (5 species and 3 species respectively), with only 1-2 species reported for the 19 remaining families. However, the calculated UV values for plants that belong to Lamiaceae family are close to 0 whilst only Rosa canina, which belongs to Rosaceae, showed similar UV value. In contrast, the highest UV value (0.84) was registered for Lawsonia inermis, which belongs to the Lythraceae family.

\section{Traditional treatment of hair and scalp disorders using animal and/or mineral extracts}

Similarly to the above-mentioned disorders, hair loss, split hair endings and hair damage were widely mentioned with a Fic equal to 0.94. However, the highest Fic (1) was recorded for the enhancing of hair color.

\section{Traditional preparation method of the natural Cosmeceuticals for hair and scalp disorders}

Table 6 and Fig. 3 summarized the parts used as well as the method of preparation and application of herbal products to the hair and scalp. As can be seen, oils alone or oil mixtures are the most used products and they are applied or rubbed directly onto the scalp. In addition, olive oil was used in most herbal products, not only as a

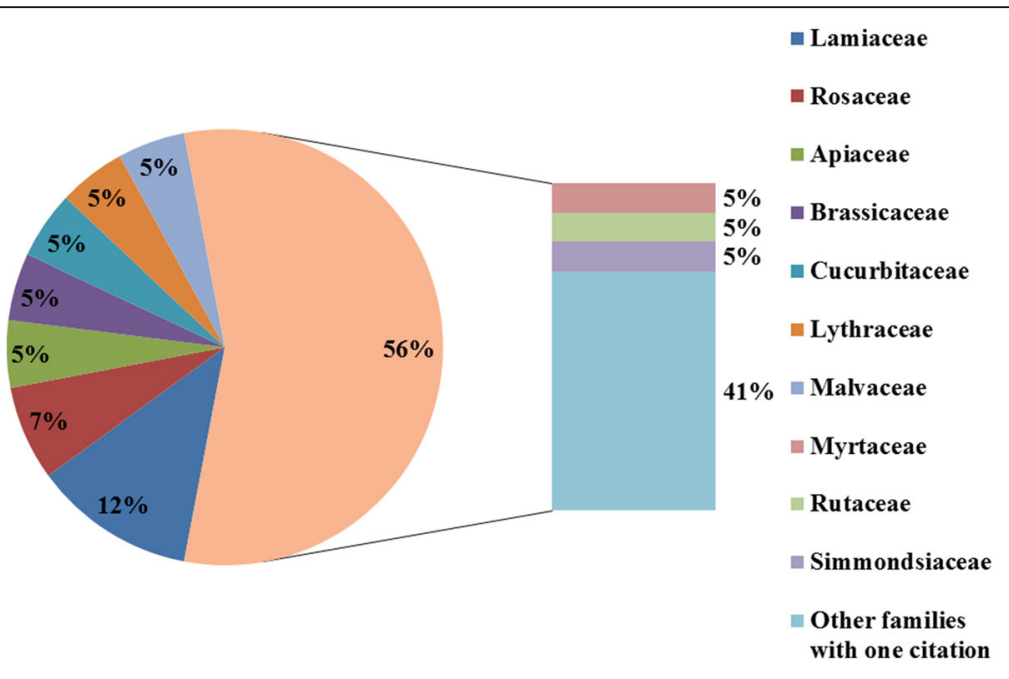

Fig. 2 Family use value for the used plants 
Table 3 Plants used as home remedies for treatment of hair and hair scalp in the West Bank/Palestine

\begin{tabular}{|c|c|c|c|c|c|c|c|c|c|c|c|c|c|}
\hline Plant name & $\begin{array}{l}\text { Hair } \\
\text { endings }\end{array}$ & $\begin{array}{l}\text { Hair } \\
\text { damage }\end{array}$ & $\begin{array}{l}\text { Hair } \\
\text { loss }\end{array}$ & Baldness & Dandruff & Lice & $\begin{array}{l}\text { Scalp } \\
\text { acne }\end{array}$ & $\begin{array}{l}\text { Alopecia } \\
\text { areata }\end{array}$ & Scabies & $\begin{array}{l}\text { Enhance the } \\
\text { color of the hair }\end{array}$ & $\begin{array}{l}\text { Hair } \\
\text { dyes }\end{array}$ & $\begin{array}{l}\text { Hair } \\
\text { cleaners }\end{array}$ & $\begin{array}{l}\text { Hair } \\
\text { conditioners }\end{array}$ \\
\hline Aloe vera & 20.0 & 13.0 & 13.0 & 6.0 & 14.0 & - & - & 6.0 & - & 6.0 & - & - & 7.0 \\
\hline $\mathrm{FL}$ & 23.5 & 15.3 & 15.3 & 7.1 & 16.5 & & & 7.1 & & 7.1 & & & 8.2 \\
\hline Prunus dulcis & 24.0 & 8.0 & 25.0 & - & 7.0 & - & 8.0 & - & - & - & - & 4.0 & - \\
\hline $\mathrm{FL}$ & 31.6 & 10.5 & 32.9 & & 9.2 & & 10.5 & & & & & 5.3 & \\
\hline Cocos nucifera & 16.0 & 14.0 & 10.0 & 4.0 & - & - & - & - & - & 9.0 & - & - & 31.0 \\
\hline $\mathrm{FL}$ & 19.0 & 16.7 & 11.9 & 4.8 & & & & & & 10.7 & & & 36.9 \\
\hline Camellia sinensis & - & - & 5.0 & 11.0 & - & 5.0 & - & - & - & 11.0 & - & - & - \\
\hline $\mathrm{FL}$ & & & 15.6 & 34.4 & & 15.6 & & & & 34.4 & & & \\
\hline Melaleuca alternifolia & - & - & - & - & - & 6.0 & & & & & & & \\
\hline $\mathrm{FL}$ & & & & & & 100.0 & & & & & & & \\
\hline
\end{tabular}

Capsicum frutescens

$\mathrm{L}$.

$\mathrm{FL}$

100.0

$\begin{array}{lll}\text { Urtica pilulifera } \quad 6.0 \quad-\quad 5.0 & -\end{array}$

$\begin{array}{lll}\mathrm{FL} & 54.5 & 45.5\end{array}$

Malus domestica

$11.0 \quad-\quad 6.0$

$\mathrm{FL}$

9.3

$6.0 \quad 5.0$

30.0

$\begin{array}{lll}31.0 & 8.0 \quad 9.0\end{array}$

4.0

$\begin{array}{lll}5.1 & 4.2 \quad 25.4\end{array}$

$\begin{array}{lll}26.3 & 6.8 & 7.6\end{array}$

3.4

5.1

Persea americana

6.0

$-\quad-$

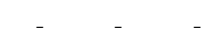

$-$

\section{$\mathrm{FL}$} $24.9 \quad 12.7$

$23.1 \quad 12.7$

8.7

Barbarea vulgaris

11.0 -

$\mathrm{FL}$

26.7

73.3

Trigonella arabica

$11.0 \quad 12.0$

23.0

4.0

$\mathrm{FL}$

Zingiber officinale

$5.0 \quad 4.0$

$$
5.0
$$

$\mathrm{FL}$

$\begin{array}{lll}35.7 & 28.6 \quad 35.7\end{array}$

Sesamum indicum

$8.0 \quad-$

4.0

$\mathrm{FL}$

Lawsonia inermis

FL

$\begin{array}{lll}4.5 & 2.2 & 2.2\end{array}$

Nigella arvensis

$12.0-$

4.0

7.0

FL

Musa paradisiaca

6.0

Petroselinum crispum

$\mathrm{FL}$

Punica granatum L.

$\mathrm{FL}$

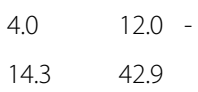

1000

100.0

Salvia fruticosa

$14.3 \quad 42.9$

$\mathrm{FL}$

Origanum syriacum 
Table 3 Plants used as home remedies for treatment of hair and hair scalp in the West Bank/Palestine (Continued)

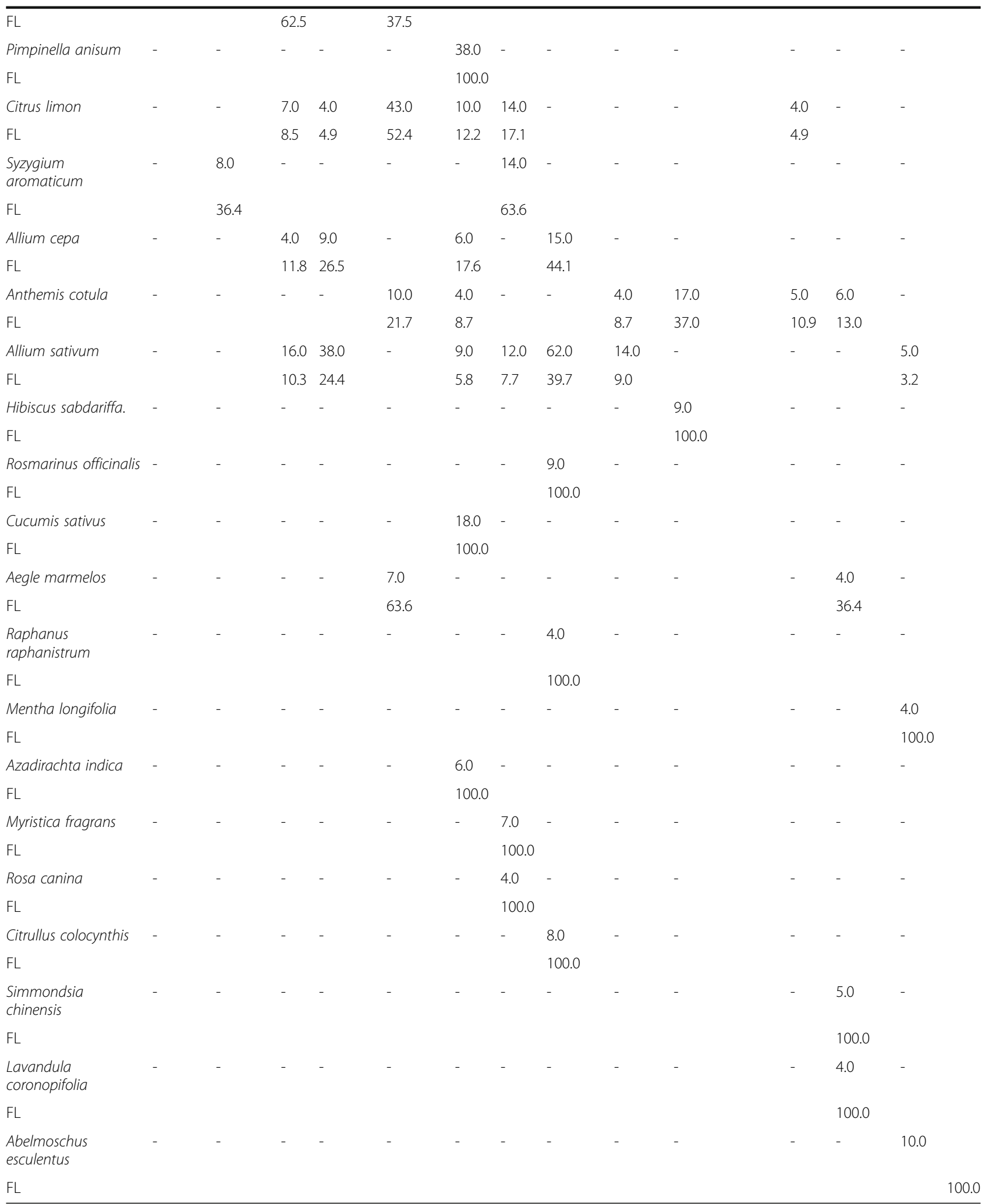




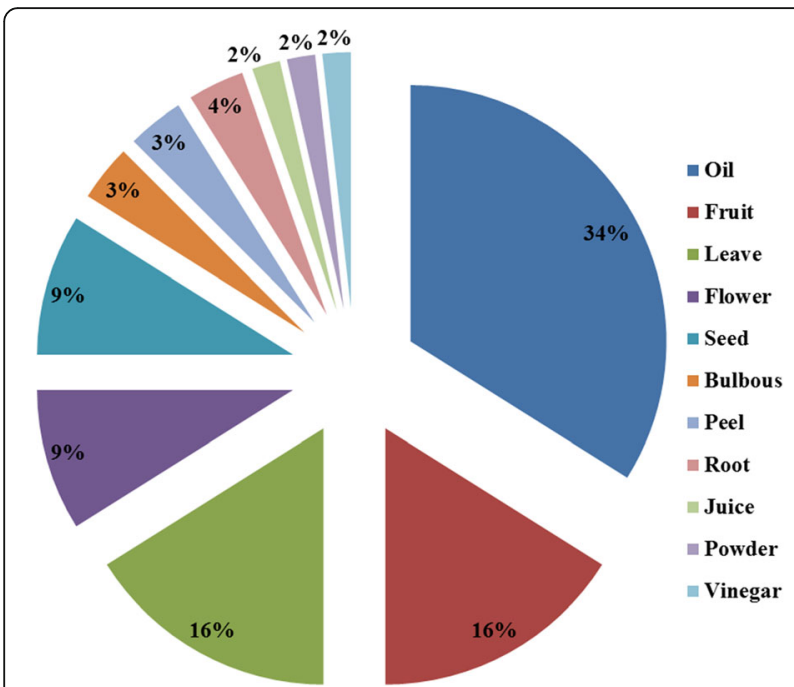

Fig. 3 The parts used of herbals in cosmetics
Table 4 Factor of informant's consensus $\left(F_{i c}\right)$ for herbals, categorized by the types of cosmeceutical treatment

\begin{tabular}{llll}
\hline Problem & Total uses & No. of plant & Fic \\
\hline Hair endings & 223 & 13 & 0.95 \\
Hair damage & 139 & 10 & 0.93 \\
Hair loss & 265 & 19 & 0.93 \\
Bladness & 135 & 11 & 0.93 \\
Dandruff & 218 & 14 & 0.94 \\
Lice & 150 & 13 & 0.92 \\
Scalp acne & 106 & 10 & 0.91 \\
Alopecia areata & 141 & 11 & 0.93 \\
Scabies & 37 & 5 & 0.89 \\
Enhance the color of the hair & 122 & 10 & 0.93 \\
Hair dyes & 144 & 4 & 0.98 \\
Hair cleaners & 65 & 8 & 0.89 \\
Hair conditioners & 196 & 12 & 0.94 \\
\hline
\end{tabular}

\section{Discussion}

Several studies have shown that around $80 \%$ of rural populations, in developing countries, consider herbal remedies as significant and important. It has been shown, in recent years, that the use of natural herbal products, has increased in both developed and developing countries, which is due to many varying, reasons [20, 21].

As shown in Table 1, most of the respondents have a high level of education, with the majority of them (62.9\%) graduating from University. The same table also showed that the majority of respondents (72.7\%) usually obtain their natural products from "Attarines", which indicates a high level of trust in these folkloric venders. It also showed that Pharmacists, who are believed to be the group of professional people with the appropriate knowledge and educational background to answer correctly about the safety and efficacy of these products, were rarely contacted regarding the use of natural products. This may imply that there is a lack of trust in these healthcare professionals or that a belief system exists that suggests that these products can be dealt with traditionally; the use of "Attarines," and that, due to their long- standing use, these natural products are considered to be safe.

In Palestine, natural cosmeceutical and nutraceutical products are frequently commercialized in herbal shops and, at a lower percentage, in Community Pharmacies and are also, often, prepared domestically. The knowledge and the attitude that people have towards domestic home cosmeceutical and nutraceutical remedies are mainly based on their traditional, folkloric uses as well as updated information. This information is generally $0.93,0.94,0.95$, and 0.92 respectively. 
Table 5 Fidelity level of other natural products used in the treatment of hair and scalp in the West Bank/Palestine

\begin{tabular}{|c|c|c|c|c|c|c|c|c|c|c|c|c|c|}
\hline Animal Product & $\begin{array}{l}\text { Hair } \\
\text { ending }\end{array}$ & $\begin{array}{l}\text { Hair } \\
\text { damage }\end{array}$ & $\begin{array}{l}\text { Hair } \\
\text { loss }\end{array}$ & Baldness & Dandruff & Lice & $\begin{array}{l}\text { Scalp } \\
\text { acne }\end{array}$ & $\begin{array}{l}\text { Alopecia } \\
\text { areata }\end{array}$ & Scabies & $\begin{array}{l}\text { Enhance hair } \\
\text { color }\end{array}$ & $\begin{array}{l}\text { Hair } \\
\text { dyes }\end{array}$ & $\begin{array}{l}\text { Hair } \\
\text { cleaners }\end{array}$ & $\begin{array}{l}\text { Hair } \\
\text { conditioners }\end{array}$ \\
\hline Egg & 28.0 & 24.0 & 30.0 & 10.0 & 10.0 & - & - & 7.0 & - & - & - & - & 21.0 \\
\hline $\mathrm{FL}$ & 21.5 & 18.5 & 23.1 & 7.7 & 7.7 & & & 5.4 & & & & & 16.2 \\
\hline Honey & 15.0 & 6.0 & 17.0 & 9.0 & 5.0 & 5.0 & 9.0 & 26.0 & - & - & - & - & 5.0 \\
\hline $\mathrm{FL}$ & 15.5 & 6.2 & 17.5 & 9.3 & 5.2 & 5.2 & 9.3 & 26.8 & & & & & 5.2 \\
\hline Yogurt & 7.0 & 12.0 & - & 4.0 & - & - & - & - & - & 3.0 & - & - & 6.0 \\
\hline $\mathrm{FL}$ & 21.9 & 37.5 & & 12.5 & & & & & & 9.4 & & & 18.8 \\
\hline Fish oil & 4.0 & - & - & - & - & - & - & - & - & - & - & - & - \\
\hline $\mathrm{FL}$ & 100.0 & & & & & & & & & & & & \\
\hline Milk & - & 7.0 & 4.0 & 4.0 & - & - & - & - & - & - & - & - & - \\
\hline $\mathrm{FL}$ & & 46.7 & 26.7 & 26.7 & & & & & & & & & \\
\hline Salt & - & - & - & - & 4.0 & - & - & - & - & - & - & - & 5.0 \\
\hline $\mathrm{FL}$ & & & & & 44.4 & & & & & & & & 55.6 \\
\hline Butter & - & - & 4.0 & - & - & - & - & - & - & - & - & - & 5.0 \\
\hline $\mathrm{FL}$ & & & 44.4 & & & & & & & & & & 55.6 \\
\hline Kerosene & - & - & - & - & - & 17.0 & - & - & - & - & - & - & - \\
\hline $\mathrm{FL}$ & & & & & & 100.0 & & & & & & & \\
\hline Mustard & - & - & - & - & - & - & - & 5.0 & - & - & - & - & - \\
\hline $\mathrm{FL}$ & & & & & & & & 100.0 & & & & & \\
\hline Mineral oil & - & - & - & - & - & 7.0 & - & - & - & - & - & - & - \\
\hline $\mathrm{FL}$ & & & & & & 100.0 & & & & & & & \\
\hline
\end{tabular}

obtained from friends' and/ or relatives as well as from the Internet. Tables 2 and 6 show the natural cosmeceutical remedies, conventionally used for decorating hair and/ or the healing of hair and scalp disorders in the studied area. Plant-derived home-made cosmetics, cosmeceuticals and remedies for hair and scalp disorders include, approximately, 56 preparation methods coming from an average of 41 botanical species, whilst remedies derived from minerals or animals are listed in Tables 2 and 6.

\section{Folk cosmetics and aesthetic values amongst Palestinian population}

Cosmetic preparations used for the: coloring or lightening of hair, prevention of hair loss or the treatment of scabies, have been included in our study. Most of the plant ingredients (Anthemis cotula, Rosa canina, Simmondsia chinensis, Lavandula coronopifolia, and Prunus dulcis) are also used today in modern phytocosmetics, whilst a few ingredients are less known, nowadays, for cosmetic purposes (Citrullus colocynthis, Abelmoschus esculentus and Aegle marmelos). From a cultural point of view, it is interesting to note how Palestinian women are still trying to find a diverse and wide range of ingredients in order to enhance their hair appearance; this usually involves the lightening or coloring of their hair to a shade of blond, which is considered a synonym of beauty for most of them. The use of chamomile paste, apple vinegar, and lemon juice indicates a new trend in the cultural concepts of aesthetics, which has been emphasized in recent years. Nowadays, in fact, blond hair, altered by cosmetic products, is normally considered a sign of beauty in Arab countries. Therefore, many women are willing to add and use any natural additives to enhance the performance of certain hair dyes such as Henna and Chamomile.

\section{Ethnocosmeceuticals}

Many reported formulations have been or are still being used to enhance the appearance of hair: lightening and coloring, prevention of hair loss and to combat scabies. Less is known about the phyto-pharmacology of the ingredients used in these preparations, they often had an emollient rule and were thought to optimize and restore the functions of the scalp and appendices, which are highly affected by a lifestyle characterized by hard daily activities. This group of remedies comprises onions, honey, eggs, aloe, fish oil, mustard, rosemary, pomegranate, and even milk. A few of these species are in fact 
Table 6 Plant products, parts used and preparation methods

\begin{tabular}{|c|c|c|}
\hline Plant name & Parts used & Preparation methods \\
\hline \multirow[t]{2}{*}{ Aloe vera } & Oil & Apply to the hair alone or with olive and other oils (like: sesame, avocado, almond and castor oil) \\
\hline & Leave & Boil the leaves and apply to hair \\
\hline Prunus dulcis & Oil & Apply to hair by rubbing \\
\hline \multirow[t]{2}{*}{ Cocos nucifera } & Oil & Apply to hair by rubbing. \\
\hline & & Can be diluted with other oils (olive, sesame, castor) and applied to hair. \\
\hline Camellia sinensis & Leaves & Soak in warm water and apply. \\
\hline Melaleuca alternifolia & Oil & Apply to hair by rubbing. \\
\hline Capsicum frutescens & Fruit & Smashed and mixed with olive oil and vinegar and applied topically. \\
\hline Urtica pilulifera & Leaves & Smashed and mixed with olive oil and applied topically. \\
\hline Malus domestica & Vinegar & Dilute with water and apply, can mix with olive oil before its application. \\
\hline \multirow[t]{2}{*}{ Persea americana } & Oil & Apply to hair by rubbing (can mix with other oils like, olive, coconut, aloe). \\
\hline & Fruit & Smash the fruit and mix with olive oil and apply topically. \\
\hline \multirow[t]{2}{*}{ Olea europaea } & Oil & Apply by rubbing. \\
\hline & & Prepare in soap and use for cleansing. \\
\hline \multirow[t]{2}{*}{ Ricinus communis } & Oil & Apply by rubbing. \\
\hline & & Dilute with olive oil and rube. \\
\hline \multirow[t]{2}{*}{ Barbarea vulgaris } & Oil & Soak in water and apply to the hair \\
\hline & Leave & \\
\hline \multirow[t]{2}{*}{ Trigonella arabica } & Oil & Apply the oil by rubbing after mixing with mustard and olive oil. \\
\hline & Seed & Soak the seed in warm water blend and apply \\
\hline \multirow[t]{2}{*}{ Zingiber officinale } & Root & Smash the roots boil in water and apply \\
\hline & Oil & \\
\hline Sesamum indicum & Oil & Apply by rubbing, can mix with other oils (Castor, olive and coconut) \\
\hline \multirow[t]{3}{*}{ Lawsonia inermis } & Leave & Mill the leaves, then knead the powder with warm water and apply for 30 min, then wash \\
\hline & Powder & Apply after kneading with warm water and green tea \\
\hline & & Apply after kneading with warm water \\
\hline \multirow[t]{2}{*}{ Nigella arvensis } & Oil & Apply the oil by rubbing after mixing with honey and watercress and olive oils \\
\hline & Seed & Mill the seed, soak in warm water and mix with watercress then apply \\
\hline \multirow[t]{2}{*}{ Musa paradisiaca } & Fruit & Smashed, boiled for $10 \mathrm{~min}$ and mixed with olive oil then applied to the hair \\
\hline & Peel & \\
\hline \multirow[t]{2}{*}{ Petroselinum crispum } & Leave & Boil in water and apply \\
\hline & Seed & \\
\hline \multirow[t]{2}{*}{ Punica granatum } & Fruit & Squeeze and apply \\
\hline & Peel & Mill the peel, soak with warm water and apply \\
\hline \multirow[t]{2}{*}{ Salvia fruticosa } & Leave & Boil in water and apply \\
\hline & Flower & \\
\hline \multirow[t]{2}{*}{ Origanum syriacum } & Leave & Boil in water and apply \\
\hline & Oil & Apply the oil by rubbing, also can be mixed with other oils (olive, castor and avocado) \\
\hline Pimpinella anisum & Oil & Apply by rubbing, can mix with olive and castor oil \\
\hline \multirow[t]{2}{*}{ Citrus limon } & Fruit & Squeeze the fruit then mix the juice with olive oil and apply \\
\hline & Juice & \\
\hline \multirow[t]{2}{*}{ Syzygium aromaticum } & Oil & Apply by rubbing, can mix with olive oil. \\
\hline & Flower & Mill and soak with water and mix with garlic then apply. \\
\hline Allium cepa & Bulbous & Squeeze mix with ginger and oils (olive, caster and aloe) then apply \\
\hline
\end{tabular}


Table 6 Plant products, parts used and preparation methods (Continued)

\begin{tabular}{lll}
\hline Anthemis cotula & Flower & Boil in water and apply \\
Allium sativum & Bulbous & Smash the garlic mix with yogurt and apply \\
Hibiscus sabdariffa & Oil & Apply the oil by rubbing \\
Rosmarinus & Flower & Soak in warm water and apply to hair \\
Cucumis sativus & Leave & Boil in water and apply \\
Aegle marmelos & Fruit & Squeeze and mix with oil and apply \\
& Fruit & Boil in water blend and apply \\
Raphanus raphanistrum & Seed & Mill the seed and soak in warm water then apply \\
Mentha longifolia & Root & Squeeze and blend with other oils (castor, olive) \\
Azadirachta indica & Apply the oil by rubbing, can be diluted with olive oil \\
Myristica fragrans & Leave & Boil the leaves and wash the hair 1 h before bath \\
Rosa canina & Seed & Apply to hair by rubbing \\
Citrullus colocynthis & Soak in water blend and apply, can mix with oils \\
Simmondsia chinensis & Fruit & Apply by rubbing \\
Lavandula coronopifolia & Oil & Blend and apply \\
Abelmoschus esculentus & Fruit & Mix with olive, watercress and castor oil then apply by rubbing \\
\hline
\end{tabular}

medicinal plants, well-known in the modern, evidencebased European and also Mediterranean and Arab phytotherapy herbal treatise of the past five centuries [22].

\section{Ingredients of animal and mineral origin}

Bee products (wax and honey), milk products (yogurt, fresh milk, and butter), eggs and even kerosene represent the most commonly reported ingredients of non

Table 7 Minerals and animal products and their preparation methods

\begin{tabular}{ll}
\hline Name & Preparation methods \\
\hline Egg & Mix with olive oil and garlic then apply. \\
& Mix with honey and Turmeric and apply. \\
Honey & Dilute with water and apply by rubbing. \\
& Mix with egg and Turmeric and apply by rubbing. \\
Yogurt & Apply by rubbing. \\
& Mix with egg and apply by rubbing. \\
Fish oil & Dilute with olive oil and apply by rubbing. \\
& Mix with egg and apply \\
Milk & Mix with Turmeric and honey then apply by rubbing. \\
Salt & Mix with water and apply. \\
Butter & Mix with egg and apply \\
Kerosene & Apply by rubbing. \\
Mustard & Mix with honey and apply by rubbing. \\
Mineral oil & Mix with olive oil and apply by rubbing
\end{tabular}

herbal origin used cosmetically by rural women (Table 2). A few of these ingredients were used as excipients and active ingredients at the same time, mainly as emollients, whilst others, such as kerosene, were used as pesticides.

\section{Historical considerations}

Similar to other studies conducted on home cosmeceutical remedies, we can deduct that traditional Palestinian

Table 8 Factor of informant's consensus $\left(F_{i c}\right)$ for minerals and animals products, categorized by the types of cosmeceutical treatment

\begin{tabular}{llll}
\hline Problem & Nur & $\mathrm{Nt}$ & Fic \\
\hline Hair endings & 54 & 4 & 0.94 \\
Hair damage & 49 & 4 & 0.94 \\
Hair loss & 55 & 4 & 0.94 \\
Bladness & 27 & 4 & 0.88 \\
Dandruff & 19 & 3 & 0.89 \\
Lice & 29 & 2 & 0.96 \\
Scalp acne & 9 & 1 & 1.00 \\
Alopecia areata & 38 & 3 & 0.95 \\
Scabies & 0 & 0 & 0.00 \\
Enhance the color of the hair & 3 & 1 & 1.00 \\
Hair dyes & 0 & 0 & 0.00 \\
Hair cleaners & 0 & 0 & 0.00 \\
Hair conditioners & 42 & 5 & 0.90 \\
\hline
\end{tabular}




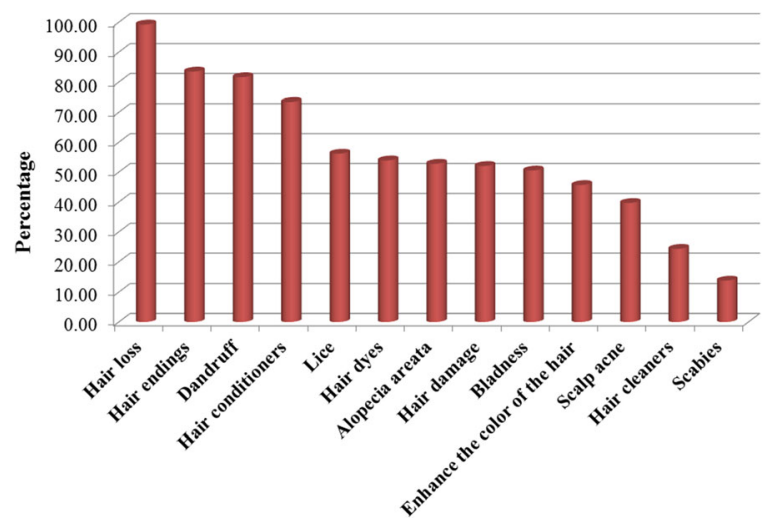

Fig. 4 Hair and scalp disorders treated by herbals

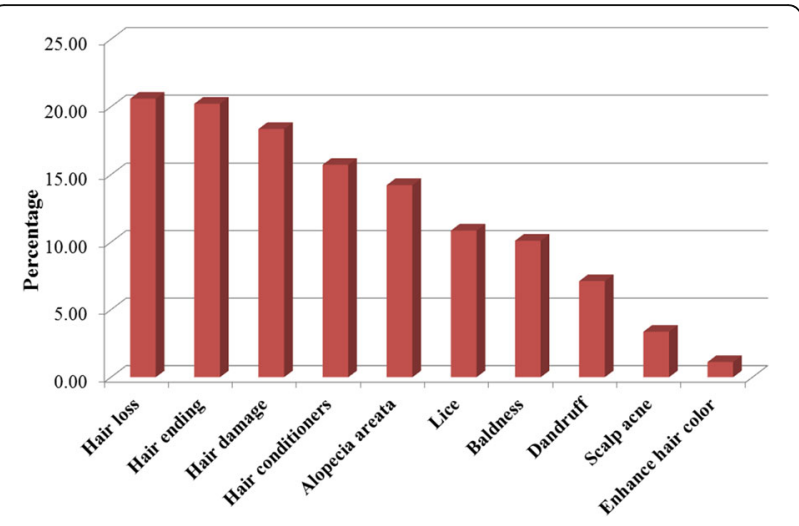

Fig. 5 Hair and scalp disorders treated by minerals and/or animals product knowledge, in the preparation of domestic home remedies and cosmeceutical products for the healing of hair and scalp disorders, rarely include exotic or expensive ingredients from the Mediterranean market. The only exception to this is represented by the use of oils extracted from Simmondsia chinensis, Lavandula coronopifolia, Pimpinella anisum, Syzygium aromaticum, and Azadirachta indica oils. Thus the Palestinian cosmetic and cosmeceutical practices have taken a different direction from the historical "schools" of cosmetics.

According to our findings, members of the Lamiaceae and Rosaceae families were the most commonly used cosmeceuticals as reported in Table 2. The methods used in the preparation of these herbal products consisted of the mixing of more than one natural product together followed by the direct application of this mixed product to the hair or scalp. This method, however, may result in low compliance as these products are often oily or have bad organoleptic properties, making them difficult to be clean without the use of strong detergents, which may, possible, have a detrimental effect on the hair and scalp. Asking for the appropriate advice and counseling from a pharmacist may resolve this issue. Pharmacists are capable of preparing these products in a more suitable form such as creams or lotions, which are easily rinsed from the hair whilst leaving a suitable odor.

As can be seen in Figs. 4 and 5, hair loss was the most common hair disorder treated with natural products including herbal, mineral or/and plant remedies. This was then followed by hair ending damage, dandruff, hair conditioners and lice whilst scabies was the least common disorder.

Finally, most of the reported natural products in this study are edible herb, mineral or animal products such as honey, eggs and milk derivatives. Moreover, they are used externally and so minor restrictions would be applied, as they have the minimum risk in comparison to the synthetic cosmetic or cosmeceutical products. This excludes the unsuitable preparation methods that were mentioned before.

This study is of great importance as it helps to preserve and improve the knowledge of herbal, mineral and animal products used as cosmeceuticals and nutraceuticals, for hair and scalp disorders, by women in the West Bank.

In the present study Olea europaea, Lawsonia inermis, Ricinus communis, Allium sativum, Aloe vera, Cocos nucifera, Trigonella arabica, Prunus dulcis, Citrus limon, Pimpinella anisum, Punica granatum and Sesamum indicum were the most frequently used plants as home remedies for the treatments of the hair and scalp. Table 9 summarizes published cosmeceutical and skin uses of these frequently used plants.

\section{Conclusion}

Many, different, plant species are still, currently being used by herbalists and traditional practitioner healers in Palestine today, for the treatment of various types of medical conditions. This is the first study that assesses the usage, by Palestinian women, of these natural products as cosmetics or cosmeceuticals for hair and scalp disorders and afflictions. Moreover, this study is of great importance as it improves our understanding of the folkloric use of these natural products. A combined scientific effort between informants and the scientific community, working in this field, may help in the discovery of new cosmetics, cosmeceutical and nutraceutical products. Moreover, pharmacists should play a much more significant role in the preparation of suitable formulations of these products, in order to improve user compliance toward these products. 
Table 9 Summarizes published cosmeceutical and skin uses of these frequently used plants

\begin{tabular}{|c|c|c|c|}
\hline Plant species & $\begin{array}{l}\text { Reported ethnopharmacological } \\
\text { use with reference source }\end{array}$ & $\begin{array}{l}\text { Cosmeceutical and skin uses } \\
\text { with reference source }\end{array}$ & $\begin{array}{l}\text { Side effects and toxicity } \\
\text { with reference source }\end{array}$ \\
\hline Olea europaea & $\begin{array}{l}\text { Reported usage in ethnomedicine in } \\
\text { Palestine [23], Italy [24], Spain, and } \\
\text { other Mediterranean areas [25]. }\end{array}$ & To prevent hair loss and skin cleanser [26]. & $\begin{array}{l}\text { Leaves cause hepato-cellular and } \\
\text { renal abnormality [27]. }\end{array}$ \\
\hline Lawsonia inermis & $\begin{array}{l}\text { Reported in Africa [28], Southern Asia } \\
\text { specially India [29], Palestine [30], and } \\
\text { worldwide [31]. }\end{array}$ & $\begin{array}{l}\text { Coloring material, fungicidal and anti- } \\
\text { inflammatory [32]. }\end{array}$ & $\begin{array}{l}\text { It may cause loss of body balance, } \\
\text { and paralysis [33]. }\end{array}$ \\
\hline Ricinus communis & Reported in India [23] & $\begin{array}{l}\text { Reported its anti-inflammatory [34], } \\
\text { antimicrobial and antifungal activities [35]. }\end{array}$ & No significant toxic effects [36]. \\
\hline Allium sativum & Reported in developing countries [37] & Reported as antiseptic and expectorant [38] & $\begin{array}{l}\text { Reported to have toxic potential, } \\
\text { with a demonstrated capability to alter } \\
\text { biochemical indices in vital tissues [39] }\end{array}$ \\
\hline Aloe vera & $\begin{array}{l}\text { Reported in southern Africa [40], } \\
\text { Nigeria [41], Mediterranean countries } \\
\text { [42], Asia [43] and } \\
\text { India [44] }\end{array}$ & $\begin{array}{l}\text { Reported in treatment of dry skin, improve } \\
\text { the skin integrity, decrease appearance of } \\
\text { acne wrinkle and decrease erythema [45] }\end{array}$ & $\begin{array}{l}\text { Overdose reported to lead to colicky } \\
\text { abdominal spasms and pain, as well } \\
\text { as the formation of thin, watery stools [46] }\end{array}$ \\
\hline Cocos nucifera & $\begin{array}{l}\text { Reported in Southeast Asia [47], } \\
\text { India [48], Africa [49], and American } \\
\text { continent [50]. }\end{array}$ & $\begin{array}{l}\text { Reported as Anti-bacterial, antifungal [51], } \\
\text { preventing hair loss, wound healing, and } \\
\text { dermatitis [52],. }\end{array}$ & Low toxicity effect reported [53]. \\
\hline Trigonella arabica & $\begin{array}{l}\text { Reported in India, Africa [54], and } \\
\text { Egypt [55]. }\end{array}$ & Treatment of inflammation [56] & $\begin{array}{l}\text { Administration at higher dose induced } \\
\text { toxicity including teratogenic, foetotoxic, } \\
\text { reproductive changes and the abnormal } \\
\text { shapes of the sperms [57] }\end{array}$ \\
\hline Prunus dulcis & $\begin{array}{l}\text { Reported in Iraq [58] and Lebanon } \\
\text { [59] and well known } \\
\text { Worldwide }\end{array}$ & $\begin{array}{l}\text { High antioxidant activity [60] and used } \\
\text { for premature hair fall [61] }\end{array}$ & No reference \\
\hline Citrus limon & Reported throughout the world [62] & Skin care and anti-oxidants [62]. & No reference \\
\hline Pimpinella anisum & $\begin{array}{l}\text { Reported in Mediterranean Region } \\
\text { [63], Palestine [64], the Middle East [65] } \\
\text { and Spain [63] }\end{array}$ & $\begin{array}{l}\text { Reported to have insecticidal effect [66], } \\
\text { antioxidant and anti-inflammatory effect [67], }\end{array}$ & No reference \\
\hline Punica granatum & $\begin{array}{l}\text { Reported in India [68], Algeria [69], } \\
\text { Africa [70], America [71], Spain [72]. }\end{array}$ & $\begin{array}{l}\text { Evidence for in vitro assay activity as } \\
\text { antioxidant [73] and protects against the } \\
\text { adverse effects ultraviolet radiation }[74,75] \text {. }\end{array}$ & Considered as non-toxic $[76,77]$ \\
\hline Sesamum indicum & $\begin{array}{l}\text { Reported in India [78], USA [79], Pakistan } \\
\text { [80], Africa [81], China [82] and Sudan [83]. }\end{array}$ & $\begin{array}{l}\text { Reported to have antioxidant activity [84] } \\
\text { and wound healing [85]. }\end{array}$ & Practically non-toxic [86]. \\
\hline
\end{tabular}

\section{Abbreviations}

$F_{i c:}$ Informant's Consensus; Fl: Fidelity Level; IRB: Institutional Review Board; SPSS: Statistical Package for Social Sciences; UV: Use-Value; WHO: World Health Organization

\section{Acknowledgements}

The authors acknowledge An-Najah National University for its support.

\section{Funding}

None.

\section{Availability of data and materials}

Data are all contained within the article.

\section{Authors' contributions}

AZ conceived, accomplished and designed the study, NJ, HAZ, AME and AA carried out the data obtained and drafted this paper. All researchers collected the data from the informants, revised, read and approved the final manuscript.

\section{Ethics approval and consent to participate}

The aims of this study, protocols and the informed consent forms were approved by the Institutional Review Board (IRB) at An-Najah National University (IRB archived number 9/April/2016). This study was carried out according to the requirements of the declarations of Helsinki.

\section{Consent for publication}

All authors gave their consent for the publication of the manuscript and for AZ to be the corresponding author.

\section{Competing interests}

The authors declare that they have no financial and/or non-financial competing interests.

\section{Publisher's Note}

Springer Nature remains neutral with regard to jurisdictional claims in published maps and institutional affiliations.

\section{Author details}

${ }^{1}$ Department of Pharmacy, Faculty of Medicine and Health Sciences, An-Najah National University, P.O. Box 7, Nablus, Palestine. ${ }^{2}$ Public Health Division, Faculty of Medicine and Health Sciences, An-Najah National University, P.O. Box 7, Nablus, Palestine.

Received: 20 November 2016 Accepted: 23 June 2017

Published online: 05 July 2017

\section{References}

1. Jaradat NA, Al-Ramahi R, Zaid AN, Ayesh OI, Eid AM. Ethnopharmacological survey of herbal remedies used for treatment of various types of cancer and 
their methods of preparations in the West Bank-Palestine. BMC Complement Altern Med. 2016;16:2-12.

2. Azaizeh H, Saad B, Khalil K, Said O. The state of the art of traditional Arab herbal medicine in the Eastern region of the Mediterranean: a review. Evid Based Complement Alternat Med. 2006;3:229-35.

3. Azaizeh H, Saad B, Cooper E, Said O. Traditional Arabic and Islamic medicine, a re-emerging health aid. Evid Based Complement Alternat Med. 2010;7:419-24.

4. Ben-Arye E, Samuels N. Homeopathy on the crossroads of traditional and integrative medicine in the Middle-East. J Med Person. 2015;13:65-71.

5. Poucher WA. Perfumes, cosmetics and soaps: modern cosmetics. USA Springer; 2013

6. Aftel M. Essence and alchemy: a book of perfume. London: North Point Press; 2002.

7. Manniche L. Sacred luxuries: fragrance, aromatherapy, and cosmetics in ancient Egypt. London: Opus Publishing; 1999

8. Morris ET. Scents of time: perfume from ancient Egypt to the 21st Century,works of art reproduced in this book are from the collections of the Metropolitan Museum of art. New York: Prestel; 1999.

9. Manual On The Scope Of Application Of The Cosmetics Regulation (Ec) No 12/23/2009 (Art. 2(1)(A). http://ec.europa.eu/consumers/sectors/cosmetics/ files/doc/manual_borderlines_ol_en.pdf.

10. Singhal M, Khanna S, Nasa A. Cosmeceuticals for the skin: an overview. Asian J Pharm Clin Res. 2011;4:1-6.

11. Grace R. Cosmeceuticals: functional food for the skin. Nat Foods Merchand. 2002;23:92-9

12. Saad B, Azaizeh H, Said O. Tradition and perspectives of Arab herbal medicine: a review. Evid Based Complement Alternat Med. 2005;2:475-9.

13. Ghorbani A. Clinical and experimental studies on polyherbal formulations for diabetes: current status and future prospective. J Integr Med. 2014;12: 336-45.

14. Ehrenreich B. Witches, midwives, and nurses: a history of women healers. New York: Feminist Press at Cuny; 2010.

15. Booker A, Johnston D, Heinrich M. Value chains of herbal medicinesresearch needs and key challenges in the context of ethnopharmacology. J Ethnopharmacol. 2012;140:624-33.

16. Sahoo N, Manchikanti P, Dey S. Herbal drugs: standards and regulation. Fitoterapia. 2010;81:462-71.

17. Quave C, Pieroni A. Magical healing. Traditional folk-medical practices of the vulture area of southern Italy. German: Books on Demand GmbH; 2002.

18. Yesilada E. Contribution of traditional medicine in the healthcare system of the Middle East. Chin J Integr Med. 2011;17:95-8.

19. Gazzaneo LRS, De Lucena RFP, de Albuquerque PU. Knowledge and use of medicinal plants by local specialists in an region of Atlantic Forest in the state of Pernambuco (northeastern Brazil). J Ethnobiol Ethnomed. 2005;1:1-8.

20. Li L, Zhou X, Li N, Sun M, Lv J, Xu Z. Herbal drugs against cardiovascular disease: traditional medicine and modern development. Drug Discov Today. 2015;20:1074-86.

21. Lanzotti V. Drugs based on natural compounds: recent achievements and future perspectives. Phytochem Rev. 2014;13:725-6

22. Pieroni A, Quave CL, Villanelli ML, Mangino P, Sabbatini G, Santini L, Boccetti T, Profili M, Ciccioli T, Rampa LG. Ethnopharmacognostic survey on the natural ingredients used in folk cosmetics, cosmeceuticals and remedies for healing skin diseases in the inland marches, central-Eastern Italy. J Ethnopharmacol. 2004:91:331-44.

23. Ali-Shtayeh MS, Jamous RM, Jamous RM. Complementary and alternative medicine use amongst Palestinian diabetic patients. Complement Ther Clin Pract. 2012;18:16-21.

24. Quave $C L$, Plano LR, Pantuso T, Bennett BC. Effects of extracts from Italian medicinal plants on planktonic growth, biofilm formation and adherence of methicillin-resistant Staphylococcus aureus. J Ethnopharmacol. 2008;118:418-28.

25. Hashmi MA, Khan A, Hanif M, Farooq U, Perveen S. Traditional uses, phytochemistry, and pharmacology of Olea europaea (olive). Evid Based Complement Alternat Med. 2015;2015:1-29.

26. Zargari A. Medicinal plants. Tehran: Tehran University Publications; 1997.

27. Omer SA, Elobeid M, Elamin M, Hassan Z, Virk P, Daghestani M, Al-Olayan E, Al-Eisa NA, Almarhoon Z. Toxicity of olive leaves (Olea europaea L.) in Wistar albino rats. Asian J Anim Vet Adv. 2012;7:1175-82.

28. Boubaya A, Hannachi H, Marzougui N, Triki T, Guasmi F, Ferchichi A. Genetic diversity assessment of Lawsonia inermis germplasm in Tunisian coastal oases by ISSR and RAPD markers. Dendrobiology. 2013;69
29. Lavhale MS, Mishra S. Nutritional and therapeutic potential of Ailanthus Excelsa-a review. Pharm Rev. 2007:1:106-16.

30. Shanab A, Ali B, Adwan GM, Adwan KM, Abu Shanab FB. Efficacy of aqueous and ethanol extracts of some Palestinian medicinal plants for potential antibacterial activity. Islamic Univ J. 2008;16:77-86.

31. Fariba B, Hassan R, Homeyra E. In vitro study of the effects of henna extracts (Lawsonia inermis) on Malassezia species. Jundishapur J Microbiol. 2010; 2010:125-8.

32. Ahmadian S, Fakhree MAA. Henna (Lawsonia inermis) might be used to prevent mycotic infection. Med Hypotheses. 2009;73:629-30.

33. Mudi S, Ibrahim H, Bala M. Acute toxicity studies of the aqueous root extract of Lawsonia inermis Linn. In rats. J Med Plant Res. 2011:5:5123-6.

34. Ilavarasan $\mathrm{R}$, Mallika M, Venkataraman S. Anti-inflammatory and free radical scavenging activity of Ricinus communis root extract. J Ethnopharmacol. 2006:103:478-80.

35. Panghal $M$, Kaushal V, Yadav JP. In vitro antimicrobial activity of ten medicinal plants against clinical isolates of oral cancer cases. Ann Clin Microbiol Antimicrob. 2011;10:1.

36. Sadashiv PS. Acute toxicity study for Ricinus communis. Pharm Lett. 2011;3: $132-7$.

37. Adeyemi OS, Fambegbe M, Daniyan OR, Nwajei I. Yoyo bitters, a polyherbal formulation influenced some biochemical parameters in Wistar rats. J Basic Clin Physiol Pharmacol. 2012;23:135-8.

38. Mikail $\mathrm{H}$. Effect of Allium sativum (garlic) bulbs aqueous extract on T. brucei Brucei infection in rabbits. Sokoto: M. Sc. Thesis submitted to Usman Danfodiyo University; 1995

39. Sulaiman FA, Kazeem MO, Waheed AM, Temowo SO, Azeez IO, Zubair Fl, Adeyemi TA, Nyang A, Adeyemi OS. Antimicrobial and toxic potential of aqueous extracts of Allium sativum, Hibiscus sabdariffa and Zingiber officinale in Wistar rats. J Taibah Univ Sci. 2014;8:315-22.

40. Grace O, Simmonds M, Smith G, Van Wyk A. Therapeutic uses of aloe L. (Asphodelaceae) in southern Africa. J Ethnopharmacol. 2008;119:604-14.

41. Ezuruike UF, Prieto JM. The use of plants in the traditional management of diabetes in Nigeria: pharmacological and toxicological considerations. J Ethnopharmacol. 2014;155:857-924.

42. Faroogi AA, Sreeramu B. Cultivation of medicinal and aromatic crops. India: Universities Press; 2001.

43. Foster M, Hunter D, Samman S. Herbal medicine: Biomolecular and clinical aspects. Boca Raton: CRC Press/Taylor \& Francis; 2011.

44. Rajeswari R, Umadevi M, Rahale CS, Selvavenkadesh S, Kumar KS, Bhowmik D. Aloe vera: the miracle plant its medicinal and traditional uses in India. J Pharmacogn Phytochem. 2012;1:118-24.

45. West DP, Zhu YF. Evaluation of Aloe vera gel gloves in the treatment of dry skin associated with occupational exposure. Am J Infect Control. 2003;31:40-2.

46. Beuers U, Spengler U, Pape G. Hepatitis after chronic abuse of senna. Lancet. 1991;337:372-3.

47. Al-Adhroey AH, Nor ZM, Al-Mekhlafi HM, Amran AA, Mahmud R. Evaluation of the use of Cocos nucifera as antimalarial remedy in Malaysian folk medicine. J Ethnopharmacol. 2011;134:988-91.

48. Singla RK, Jaiswal N, Bhat $V$, Jagani $H$. Antioxidant and antimicrobia activities of Cocos nucifera Linn.(Arecaceae) endocarp extracts. Indo Global J Pharm Sci. 2011;1:354-61.

49. Gruca M, Blach-Overgaard A, Balslev H. African palm ethno-medicine. J Ethnopharmacol. 2015;165:227-37.

50. Sosnowska J, Balslev H. American palm ethnomedicine: a meta-analysis J Ethnobiol Ethnomed. 2009:5:1-11.

51. Jose M, Sharma BB, Shantaram $M$, Ahmed SA. Ethnomedicinal herbs used in oral health and hygiene in coastal Dakshina Kannada. J Oral Health Comm Dent. 2011;5:107-11.

52. Sachs M, Von Eichel J, Asskali F. Wound management with coconut oil in Indonesian folk medicine. Chirurg. 2002;73:387-92.

53. Costa C, Bevilaqua C, Morais S, Camurça-Vasconcelos A, Maciel M, Braga R, Oliveira L. Anthelmintic activity of Cocos nucifera L. on intestinal nematodes of mice. Res Vet Sci. 2010;88:101-3.

54. Van Wyk B-E. A review of commercially important African medicinal plants. J Ethnopharmacol. 2015;176:118-34.

55. AbouZid SF, Mohamed AA. Survey on medicinal plants and spices used in Beni-Sueif, upper Egypt. J Ethnobiol Ethnomed. 2011;7:1-6.

56. Narasimhamurthy K, Viswanatha S, Ramesh B. Acute and subchronic toxicity assessment of debitterized fenugreek powder in the mouse and rat. Food Chem Toxicol. 1999;37:831-8. 
57. Al-Yahya AA. Reproductive, cytological and biochemical toxicity of fenugreek in male Swiss albino mice. Afr J Pharm Pharmacol. 2013;7:2072-80.

58. Ahmed HM. Ethnopharmacobotanical study on the medicinal plants used by herbalists in Sulaymaniyah Province, Kurdistan, Iraq. J Ethnobiol Ethnomed. 2016;12:1-17.

59. Baydoun S, Chalak L, Dalleh H, Arnold N. Ethnopharmacological survey of medicinal plants used in traditional medicine by the communities of mount Hermon, Lebanon. J Ethnopharmacol. 2015;173:139-56.

60. Takeoka GR, Dao LT. Antioxidant constituents of almond [Prunus dulcis (Mill.) DA Webb] hulls. J Agric Food Chem. 2003;51:496-501.

61. Suraja R, Rejithaa G, Sunilsona JAJ, Anandarajagopala K, Promwichita P. In vivo hair growth activity of Prunus dulcis seeds in rats. Biol Med. 2009;1:34-8.

62. Mohanapriya M, Ramaswamy DL, Rajendran DR. Health and medicinal properties of lemon (Citrus limonum). J Ayu Her Med. 2013;3:1095-100.

63. Salehi SM. Medicinal plants and Phytotherapy. Tehran: Donyay Taghziah Press; 2010.

64. Al R', Jaradat N, Zaid AN, Vincieri FF, Asmaa M. Medicinal herbs and methodologies for their pharmaceutical compounding in the West Bank/ Palestine. Complement Ther Clin Pract. 2014;20:280-4.

65. Ben-Arye E, Schiff E, Hassan E, Mutafoglu K, Lev-Ari S, Steiner M, Lavie O, Polliack A, Silbermann M, Lev E. Integrative oncology in the Middle East: from traditional herbal knowledge to contemporary cancer care. Ann Oncol. 2012;23:211-21.

66. Park IK, Choi KS, Kim DH, Choi IH, Kim LS, Bak WC, Choi JW, Shin SC. Fumigant activity of plant essential oils and components from horseradish (Armoracia rusticana), anise (Pimpinella anisum) and garlic (Allium sativum) oils against Lycoriella Ingenua (Diptera: Sciaridae). Pest Manag Sci. 2006;62:723-8.

67. Singh G, Kapoor I, Singh P, de Heluani C, Catalan C. Chemical composition and antioxidant potential of essential oil and oleoresins from anise seeds (Pimpinella anisum L.). Int J Essen Oil Ther. 2008;2:122-30.

68. Duraipandiyan $\mathrm{V}$, Ayyanar M, Ignacimuthu S. Antimicrobial activity of some ethnomedicinal plants used by Paliyar tribe from Tamil Nadu, India. BMC Complement Altern Med. 2006:6:1-7.

69. Kanoun K, Abbouni B, Gabbés S, Dellani S, Zizi N. In-vitro antibacterial activity of Algerian pomegranate (Punica granatum linn) peels on some antibiotic resistant gram-negative and positive bacterial strains. Middle-East J Sci Res. 2014:21:1579-89.

70. Das AK, Mandal SC, Banerjee SK, Sinha S, Das J, Saha B, Pal M. Studies on antidiarrhoeal activity of Punica granatum seed extract in rats. J Ethnopharmacol. 1999;68:205-8.

71. de Nigris F, Williams-Ignarro S, Lerman LO, Crimi E, Botti C, Mansueto G, D'Armiento FP, De Rosa G, Sica V, Ignarro LJ. Beneficial effects of pomegranate juice on oxidation-sensitive genes and endothelial nitric oxide synthase activity at sites of perturbed shear stress. Proc Natl Acad Sci U S A. 2005;102:4896-901.

72. Jurenka J. Therapeutic applications of pomegranate (Punica granatum L.): a review. Altern Med Rev. 2008;13:128-44.

73. Gil MI, Tomás-Barberán FA, Hess-Pierce B, Holcroft DM, Kader AA. Antioxidant activity of pomegranate juice and its relationship with phenolic composition and processing. J Agric Food Chem. 2000:48:4581-9.

74. Afaq F, Malik A, Syed D, Maes D, Matsui MS, Mukhtar H. Pomegranate fruit extract modulates UV-B-mediated Phosphorylation of Mitogen-activated protein Kinases and activation of nuclear factor kappa $B$ in normal human epidermal Keratinocytes. Photochem Photobiol. 2005;81:38-45.

75. Syed DN, Malik A, Hadi N, Sarfaraz S, Afaq F, Mukhtar H. Photochemopreventive effect of pomegranate fruit extract on UVAmediated activation of cellular pathways in normal human epidermal Keratinocytes. Photochem Photobiol. 2006:82:398-405.

76. Bhandary BSK, Sharmila K, Kumari NS, Bhat SV. Acute and subacute toxicity study of the ethanol extracts of Punica granatum (Linn). Whole fruit and seeds and synthetic ellagic acid in swiss albino mice. Asian J Pharm Clin Res. 2013:6:192-8.

77. Vidal A, Fallarero A, Peña BR, Medina ME, Gra B, Rivera F, Gutierrez Y, Vuorela PM. Studies on the toxicity of Punica granatum L.(Punicaceae) whole fruit extracts. J Ethnopharmacol. 2003:89:295-300.

78. Shah N. Sesamum indicum (sesame or Til): seeds \& oil-an historical and scientific evaluation from Indian perspective. Indian J Hist Sci. 2014:48:151-74.

79. Morris J. Characterization of sesame (Sesamum indicum L.) germplasm regenerated in Georgia, USA. Genet Resour Crop Evol. 2009:56:925-36.
80. Akbar F, Rabbani MA, Masood MS, Shinwari ZK. Genetic diversity of sesame (Sesamum indicum L.) germplasm from Pakistan using RAPD markers. Pak J Bot. 2011;43:2153-60.

81. Bedigian D. Slimy leaves and oily seeds: distribution and use of wild relatives of sesame in Africa. Econ Bot. 2004;58:S3-S33.

82. Mahomoodally MF, Muthoorah LD. An ethnopharmacological survey of natural remedies used by the Chinese community in Mauritius. Asian Pac J Trop Biomed. 2014;4:387-99.

83. Abou-Gharbia HA, Shehata AAY, Shahidi F. Effect of processing on oxidative stability and lipid classes of sesame oil. Food Res Int. 2000;33:331-40.

84. Bopitiya D, Madhujith T. Antioxidant activity and total phenolic content of sesame (Sesamum indicum L.) seed oil. Trop Agric Res. 2015;24:296-302.

85. Kiran $K$, Asad M. Wound healing activity of Sesamum indicum $L$ seed and oil in rats. Indian J Exp Biol. 2008;46:777-82.

86. Ahmed M. Acute toxicity (lethal dose 50 calculation) of herbal drug Somina in rats and mice. Pharmacol Pharm. 2015;6:185-9.

\section{Submit your next manuscript to BioMed Central and we will help you at every step:}

- We accept pre-submission inquiries

- Our selector tool helps you to find the most relevant journal

- We provide round the clock customer support

- Convenient online submission

- Thorough peer review

- Inclusion in PubMed and all major indexing services

- Maximum visibility for your research

Submit your manuscript at www.biomedcentral.com/submit 